set up, including writers, lawyers, historians and scientists. Among those already subjected to reprisals, biochemist Piotr Naumski has already suffered a short term of arrest, while Miroslaw Chojewski, a chemist, has been dismissed from his post at the Institute of Nuclear Research in Swierk.

A letter from the Defence Committee to Academician Andrei Sakharov, appealing to his "moral authority and fellow-feeling", evoked a declaration from him that although he did not know what concerted actions could, at the present time, be aligned with the actions of the Polish defence committee, he was nevertheless seeking ways in which the Soviet human rights movement could "effectively cooperate" with similar movements throughout Eastern Europe.

There seems to be enough dissident activity to suggest that the time is ripe for such a concerted effort, if only one of moral support. In the Soviet Union a press campaign has been launched against Aleksandr Voronel, the founder of the illegal "Sunday seminar" for Jewish refusniks, denouncing him as a traitor. The seminar, which survived Voronel's departure for Israel in December 1974, is now approaching its fifth anniversary, and is planning a special Jubilee session (Sakharov is to be on the jubilee Committee). Nevertheless pressure on the Seminar continues; recently several of its leading members, including physicist Mark Azbel, the organiser, were held by the police for several days.

In East Germany, the chemist Robert Havemann is subject to house arrest, for having protested against the exiling of Wolf Biermann, the dissident poet and ballad-singer. Havemann's dissident "career" dates back to 1964, when he was dismissed (on account of his "revisionist" views) from his post as Professor of Physical Chemistry at the Humboldt University, Berlin.

From Bulgaria it is understood that an attempt to disseminate some controversial material in samizdat form led to the removal of their author (a physicist) to a mental hospital. Although he was subsequently discharged, he was not reinstated in his university post but was instead retired on a disability pension, thereby effectively removing his ability to speak from a position of authority.

This appears to mark a new development. The dissemination of Soviet technology and ideas among the countries of the Socialist block is a basic concept of Comecon. So far, however, the incarceration of dissidents in mental institutions has been primarily a Soviet phenomenon, although there have been hints of isolated cases in Czechoslovakia and the German Democratic Republic.

- Lord Todd had some words to say last week on the Royal Society's role regarding scientists and human rights. Delivering the Society's Anniversary Address, he said it was hard to see in what way the Society could occupy a special position. He pointed to the Society's adherence to the Declaration issued by the International Council of Scientific Unions and by its cooperation with that hody in efforts to uphold it in all its member countries. In appropriate cases, he said,

the Society has drawn and will continue to draw the attention of the Soviet Academy of Sciences or the corresponding body in any other country concerned, as well as our own Government, to the facts and to the need for action with. I believe, good effect. It is my firm belief that the Society as such can achieve much more in this way than it can by subscribing to or issuing public declarations. For it must be recognised that a scientist. as such, is in the same position as any other citizen of his country, subject to the same laws and having the same obligations to the society in which he lives. His profession does not entitle him to special privileges which are denied to his fellow citizens; nor should it deny to him those privileges which are the right of every man.

\title{
WEST GERMANY
}

\section{Reactor reactions}

A Correspondent reports on recent developments on the nuclear power front in the German Federal Republic.

THE future of nuclear power in West Germany depends critically on imminent decisions over the construction of nuclear reprocessing and storage facilities in Lower Saxony. The rumble of anti-nuclear feeling, which recently erupted in demonstrations at the Brokdorf power station site, led the Interior Minister, Werner Maihofer, to announce earlier this year that no new permits for the construction of atomic power stations would be issued until firm plans existed for dealing with spent fuel. The salt mines of Lower Saxony are considered the only suitable site for long-term waste storage. The Prime Minister of Lower Saxony was begged four weeks ago by Bonn Cabinet ministers to allow the plant to be built and seems to have been persuaded: the proposed site of the plant is to be announced soon. But determined local opposition will ensure that its path will not be smooth.

The $20 \%$ of Germans against nuclear energy probably entertain strongest fears about reprocessing and storage of nuclear fuels. But the most violent protests have been not in Lower Saxony but at the site $50 \mathrm{~km}$ north-west of Hamburg where Kraftwerk Union is beginning to build West Germany's latest nuclear power station. Brokdorf, on the Elbe, has seen two ugly confrontations between demonstrators and police in the past few weeks, with many injured. The protests are not against any particularly unsavoury feature of Brokdorf but rather against nuclear expansion in general and the way industry is steadily transforming the lower Elbe region into another Ruhr.

The protests could equally well have been focused on Biblis, another $\mathrm{Kraft}$ werk Union product and the world's biggest nuclear plant, which was forced to shut down for three months during the summer after screws had been found dislodged from a cooling pump. An even more controversial aspect of the plant is the intention of the owners, Rheinisch-Westfalische Elektriziaswerke (RWE), to increase storage capacity for spent fuel pending construction of a reprocessing plant in Germany-RWE apparently find French and British reprocessing too expensive and prefer to sit on their fuel for an extra five or six years until the first German reprocessing plant is in action. Another worry for safety-con- scious Germans is the prospect of the reactor which the chemical company BASF is to build in an urban area at Ludwigshaven. And a third reactor-that planned for Whyl on the Rhine-is as yet unstarted because of public protest. Even discounting the political element in the demonstrations, it is clear that the new anti-nuclear feeling is not to be taken lightly.

This is recognised by the Free Democratic Party, the junior party in West Germany's coalition government. who have voted at their party conference to put strict limits on new nuclear construction. Though the vote has no binding effect for the government it is thoroughly awkward for them and in particular for the Fconomics Minister, FDP member Hans Friedrichs, a strong nuclear supporter.

Altogether embarrassing timing for Siemens's announcement of its intention to take on AEG-Telcfunken's $50 \%$ of Kraftwerk Union, the leading West German power station constructor, thus becoming sole owner. But Siemens is probably the happicr of the two concerns. It is confident about the future of nuclear energy and has the resources to see the voracious and currently unprofitable Kraftwerk Union through the next few lean years. AEGTelefunken, though glad to be rid of what it sees as an albatross, is not getting a particularly good deal. 